\title{
Characterization and geostatistical modeling of reservoirs in 'Falad' field, Niger Delta, Nigeria
}

\author{
Ayodele O. Falade ${ }^{1}$ (D) John O. Amigun ${ }^{2} \cdot$ Yousif M. Makeen $^{3} \cdot$ Olatunbosun O. Kafisanwo $^{2}$
}

Received: 14 July 2021 / Accepted: 22 November 2021 / Published online: 3 December 2021

(c) The Author(s) 2021

\begin{abstract}
This research aims at characterizing and modeling delineated reservoirs in 'Falad' Field, Niger Delta, Nigeria, to mitigate the challenge caused by the heterogeneous nature of the reservoirs. Seismic and well log data were integrated, and geostatistics was applied to describe the reservoir properties of the interwell spaces within the study area. Four reservoirs, namely RES 1, RES 2, RES 3 and RES 4, were delineated and correlated across four wells. The reservoir properties \{lithology, net to gross, porosity, permeability, water saturation $\}$ of all the delineated reservoirs mapped were determined, and two reservoirs with the best quality were picked for further analysis (surface generation and modeling) after ranking the reservoirs based on their quality. Structural interpretation of the field was carried, nine faults were mapped (F1—F9), and the fault polygon was generated. The structural model showed the area is structurally controlled with two of the major faults mapped (F1 and F3) oriented in the SW-NE direction while the other one (F4) is oriented in the NW-SE direction. A 3D grid was constructed using the surfaces of the delineated reservoirs and the reservoir properties were distributed stochastically using simple krigging method with sequential Gaussian simulation, sequential indicator simulation and Gaussian random function simulation algorithms. Geostatistical modeling used in this study has been able to give subsurface information in the areas deficient of well data as the estimated reservoir properties gotten from existing wells have been spatially distributed in the study area and will thus aid future field development while also they are used in identifying new prospect by combining property models with structural maps of the area.
\end{abstract}

Keywords Seismics $\cdot$ Well logs $\cdot$ Reservoir characterization $\cdot$ Reservoir properties $\cdot$ Geostatistics $\cdot$ Niger delta

\section{Introduction}

Oil is the primary natural resource used in the world in the production of energy, but its exploration processes involve high costs and complexity of studies (BP 2014). Economically, the life of a reservoir begins with exploration leading to discovery which is followed up by characterizing the reservoir (Akeze 2009). Hydrocarbon reservoir characterization

Ayodele O. Falade

ayofalade@achievers.edu.ng; ayouseh2003@gmail.com

1 Department of Geological Sciences, College of Natural and Applied Sciences, Achievers University Owo, PMB 1030, Owo, Ondo State, Nigeria

2 Department of Applied Geophysics, School of Earth and Mineral Sciences, Federal University of Technology Akure, Akure, Ondo State, Nigeria

3 College of Earth Sciences, Jilin University, Changchun, China is referred to as a process of assigning reservoir properties through quantification by putting into consideration the geological and geophysical information (Fowler et al. 1999). Some of the importance of characterizing reservoirs is to help reduce the risks associated with the exploration and exploitation processes. The process of reservoir characterization is continuous and spans from discovery, well and field sanction to the last phases of hydrocarbon field development and production (Chopra and Marfurt 2007; Chambers and Yarus 2010). The geological and geophysical information of the subsurface changes from place to place, and to make a substantial description of the physical properties of a reservoir, a multidisciplinary approach that integrates information and knowledge from different disciplines like geophysics, geology, petrophysics, artificial intelligence, geostatistics, petroleum and reservoir engineering is used (Davis 1999).

There is continuous exploration activities going on in the Niger Delta basin of Nigeria and several methods have been adopted in past researches (Short and Stauble 1967; Weber 
and Daukoru 1975; Azeez 1976). Seismic method brought breakthrough and advancement in the hydrocarbon exploration processes (Gadallah and Fisher 2009). Seismic survey method is the principal method used by the petroleum industry to get leads to quantification of the available oil and gas for production from a field or assessment of the potentiality of an undeveloped resource. Geologic features like faults and folds that support hydrocarbon accumulation in the subsurface are defined from seismic data during exploration. Seismic data are also important in estimating the structure of reservoir bodies (Chapin et al. 2002; Li et al. 2003; Liu et al. 2005). Seismic data are commonly integrated with well $\log$ data when exploring for hydrocarbon exploration (Kafisanwo et al. 2018). Well log data are utilized to infer petrophysical information such as lithology, the volume of shale, net to gross ratio (NTG), permeability, porosity, water saturation, among others which provide a basis for formation evaluation (Ebong et al. 2019). Generally, a rock type that has less clay content, more significant porosity and smaller irreducible water saturation tends to be of better reservoir quality in terms of storage/flow capacity (Al-Baldaini 2014).

Subsurface imaging through seismic method reveals comprehensive information (laterally and vertically) about reservoirs that well $\log$ data would not made available (i.e., they have been used for estimating the spatial distribution of rock properties) (Mukerji 2001; Mukerji et al. 2004). The integration of results from seismic data and well log analysis are used to determine the commerciality of a known hydrocarbon prospect which instigate the initial field development plan through characterization (Hepler et al. 1998; Opara 2010; Kafisanwo et al. 2018). The spatial distribution of reservoir properties play an important role in oil reservoir management and choosing the best method is necessary. Reservoir characterization using geostatistics as a tool allows us to understand and model spatial variability in the reservoir. A stochastic model is used to predict reservoir properties in the interwell space, knowing that the distance between two points has an inverse relationship with the similarity in rock properties (i.e., similarity in rock properties decreases with the increase in distance of separation) (Fournier 1995; Contreras et al. 2005). Property modeling involves distributing properties between wells to match well data and realistically maintain the reservoir heterogeneity i.e., to describe variation in properties using different geostatistical methods (Ebong et al. 2019). Geostatistics is not like deterministic approach because it offers many plausible results (realizations) and building of a reliable reservoir model ensures that hydrocarbon exploration and exploitation program is successful as it involves spatial distribution of reservoir information which helps improve hydrocarbon management (Edigbue et al. 2015; Swinburn and Weiden 2015). In this research, reservoir characterization was carried out using Petrel software to estimate the petrophysical properties of delineated reservoirs in the study area. The distribution of the petrophysical properties were also characterized in the delineated reservoirs using simple krigging method and multiple realizations were made through sequential Gaussian simulation (SGS), sequential indicator simulation (SIS) and Gaussian random function simulation (GRFS) algorithms. The realizations were sliced vertically, compared with the well information and the realization having the highest correlation with the logs was picked. The information from these reservoir models will be significant in making decisions during field development, maintenance and recovery process.

\section{Geology of the study area}

The study area is part of the offshore Niger Delta basin that lies between longitudes $6^{\circ} 48^{\prime} \mathrm{E}-6^{\circ} 54^{\prime} \mathrm{E}$ and latitude $4^{\circ} 29^{\prime} \mathrm{N}-4^{\circ} 34^{\prime} \mathrm{N}$, in Southern Nigeria (Fig. 1) which has been proved over recent years to have favorable conditions for the entrapment, accumulation and generation of economically viable hydrocarbon. There is an abundance of closely associated source rock, reservoir, cap/seal rocks and a good trapping system as a result of lenticular nature of the reservoir horizons and the syn-sedimentary (syn-depositional) faulting. Benin, Agbada and Akata formations are characterized as the established Tertiary sequence in the Niger Delta in descending order as shown in Fig. 2 (Doust and Omatsola 1990).

Akata Formation is characterized by shale as revealed through gamma and S.P. logs (Ihunda et al. 2017). Though it is locally interbedded by sands and/or siltstones, it is predominantly characterized by low density, plastic, highpressure and undercompacted shallow marine to deepwater shale. The advancement of high energy delta into deep water led to the deposition of Akata shales. Overpressuring of the shale provides the mobile base for subsequent growth faulting and also the deposition of the overlying paralic sequence (Avbovbo 1978). The source rock that is responsible for majority of the hydrocarbon in the Niger Delta basin is the Akata shale as majority of wells drilled in the Niger Delta penetrated it. It is characterized by medium to dark gray color, fairly hard, or at places soft, gumbo-like and sandy or silty prodeltaic shales with its total depth up to 7,000 m (Evamy et al. 1978; Doust and Omatsola 1990). Agbada Formation is characterized by sequences composed of alternation of sandstones and shales. Its origin is associated with syn-sedimentary growth faulting as shown by Weber (1971) and Avbovbo (1978) to be a cyclic sequence of fluvial and marine deposits. The sandstones in this formation are medium to fine-grained and relatively clean. Shale act as caprock and the sandstones serve as the main reservoir of the delta even while they are locally calcareous, glauconitic and shaly. The thickest portion of this formation is 


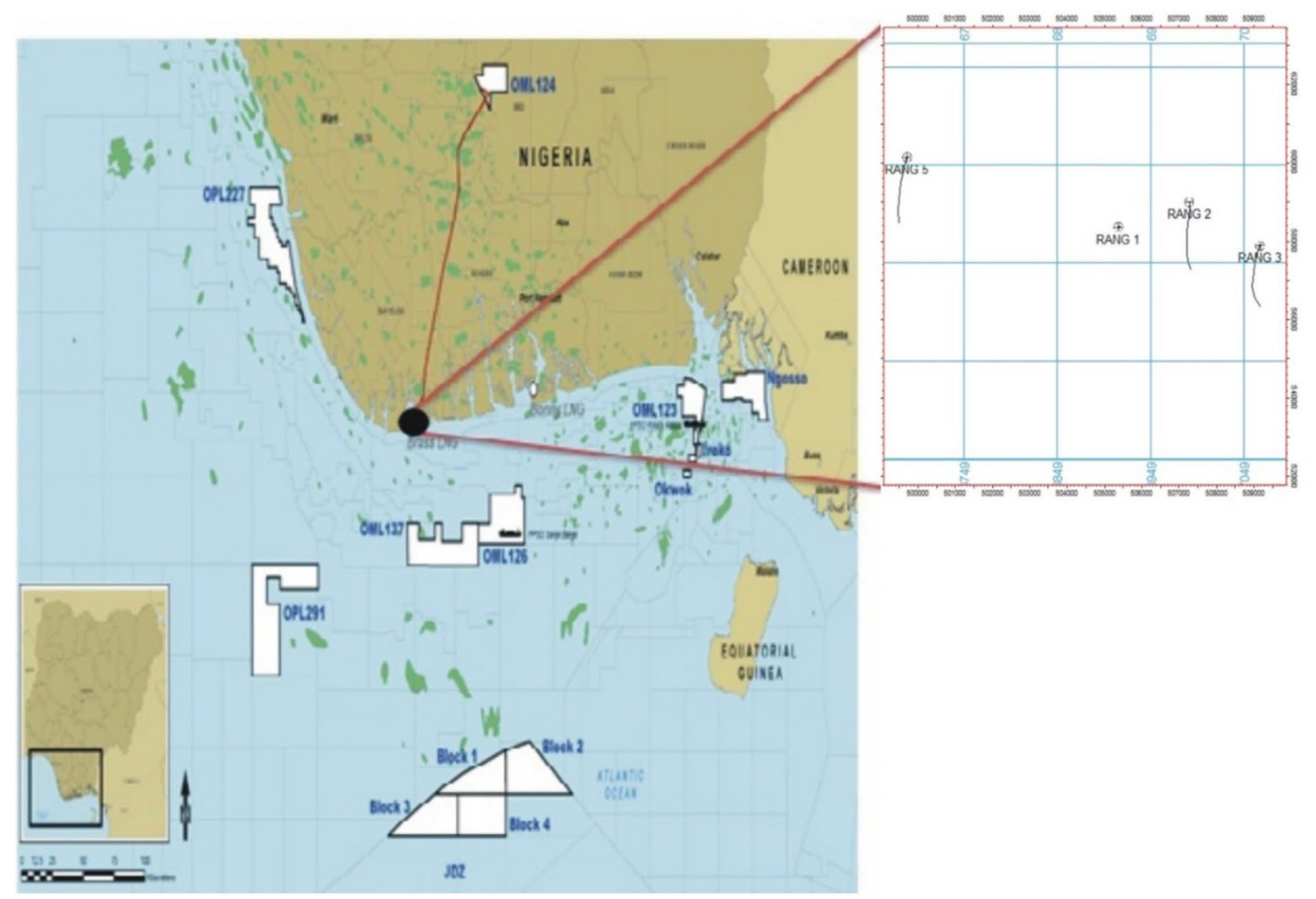

Fig. 1 Location map of study area

present at the center of the delta with total depth of about 3,940 m (Aigbedion and Aigbedion 2011). Benin Formation is predominantly characterized by sandstones that are highly porous, massive and freshwater-bearing, interbedded with thin shale considered to be originated from braided stream. The formation at the north is of Oligocene age and becomes younger to the south. To date, this highly porous formation is studied to house minimal hydrocarbon deposits. The Benin Formation as described outcrops in Benin, Onitsha and Owerri provinces as coastal plain sands that extends across the whole Niger Delta from the west (Evamy et al. 1978; Doust and Omatsola 1990).

\section{Materials and method}

The data used include 3D seismic data, suites of well log data and check shot data for four wells (Table 1) labeled as Rang 1, 2, 3 and 5 (Fig. 3). Petrel software was used in the processing and interpretation of well logs and seismic data. A methodology that suites this work was worked out to achieve the objectives of this study (Fig. 4). This workflow runs from data quality check and loading, well log correlation, petrophysical evaluation and seismic interpretation to the generation of reservoir models.

\section{Petrophysical analysis}

A detailed petrophysical evaluation was conducted for the four wells in the field. The different lithologies were identified per well using the gamma ray log and the four wells were then correlated in a NW/SE direction. The reservoir properties determined include net sand, net to gross, porosity, water saturation and permeability through the application of Eqs. 1-9.

\section{Porosity}

Porosity was determined using density and sonic logs although none of them directly measures porosity, mathematical equations were used for the computation of the porosity depending on the log used. Since porosity data are point data, average well log values and matrix values for rock and fluid types 


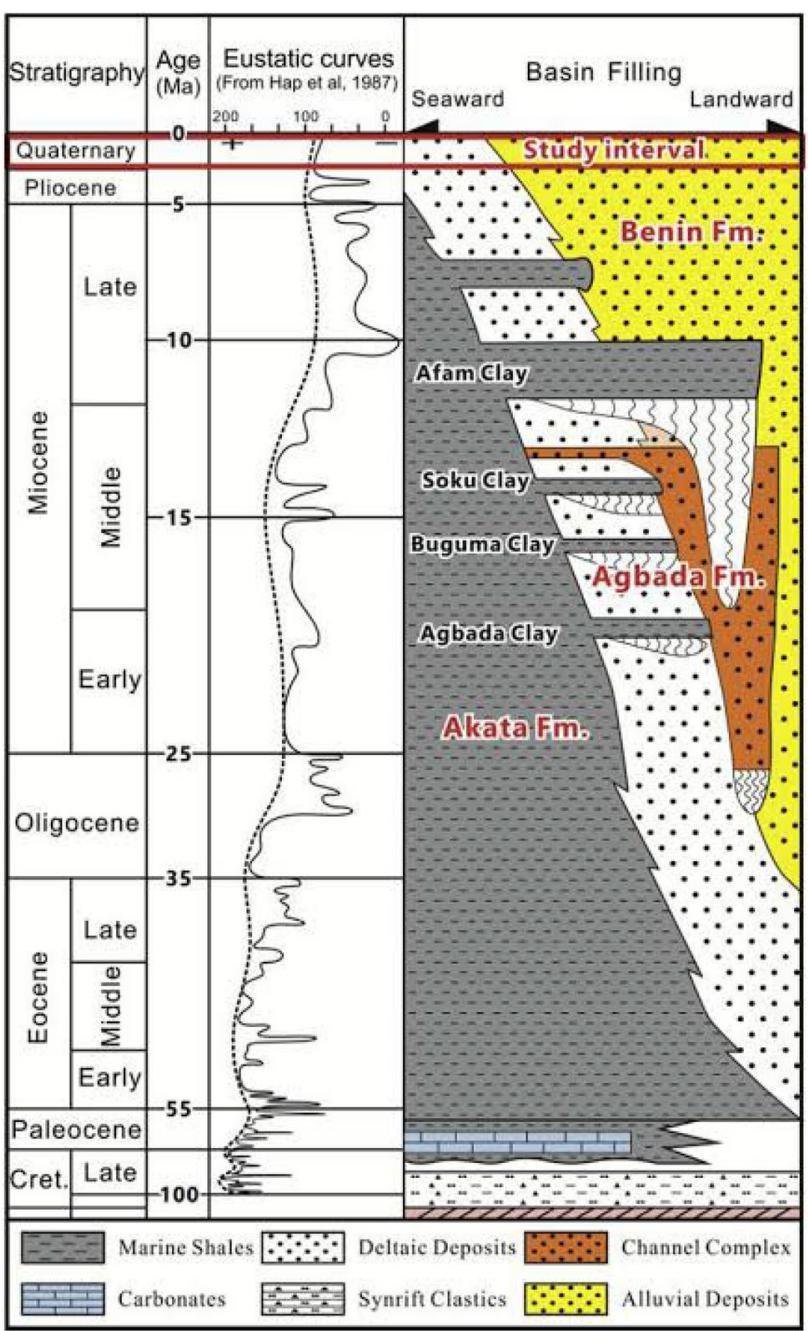

Fig. 2 Stratigraphy of Niger Delta basin ( Modified by Zhao et al. 2018 after Corredor et al. 2005)

(Table 2) were used for each reservoir to estimate for porosity (Asquit and Krygowski 2004).

Density porosity $\left(\phi_{D}\right)=\frac{\rho_{b}-\rho_{\mathrm{ma}}}{\rho_{f}-\rho_{\mathrm{ma}}}$ where $\rho_{\text {ma }}=$ Density of matrix, $\rho_{b}=$ Formation bulk density gotten from density $\log , \rho_{f}=$ fluid density.

Sonic porosity $\left(\phi_{T}\right)=\frac{\Delta T_{\mathrm{ma}}-\Delta T_{\mathrm{log}}}{\Delta T_{\mathrm{ma}}-\Delta T_{f}}$

$\Delta T_{\mathrm{ma}}=$ change in transit time of matrix, $\Delta T_{f}=$ change in transit time of fluid, $\Delta T_{\log }=$ transit time from sonic well $\log$.

Total porosity $=\sqrt{\phi_{D}^{2}-\phi_{T}^{2}}$

Effective Porosity $=$ Total Porosity

$+($ Total Porosity $\times$ Volume of Shale $)$

\section{Permeability}

Permeability is a function of how interconnected the pore spaces of a rock body are. It is mathematically derived using the equation below:

$K=\left[\frac{250(\phi)^{3}}{\mathrm{Sw}_{\mathrm{irr}}}\right]^{2}$

Where $\phi$ is the porosity

$\mathrm{Sw}_{\text {irr }}$ is the irreducible water saturation $=\sqrt{\frac{F}{2000}}$

where $\mathrm{F}$ is the formation factor $=\frac{a}{\phi^{m}}$

where a lies between 0.6 and 1 and $\mathrm{m}$ is between 1.8 and 2.15 .

\section{Water saturation}

Water saturation involves the measurement of the amount of fluid (water, gas or hydrocarbon) saturated in a particular reservoir. It is gotten by using several resistivity log readings. It is determined using the formula below:
Table 1 Available well $\log$ data for the studied wells in 'Falad' field

\begin{tabular}{lllllllll}
\hline $\begin{array}{l}\text { Log type } \\
\text { Well Name }\end{array}$ & Gamma Ray & SP & Sonic & RHOB & PHI & R-MSFL & R-LLS & R-LLD \\
\hline Well 1 & X & X & X & X & X & X & X & X \\
Well 2 & X & X & X & X & X & X & X & X \\
Well 3 & X & X & X & & X & X & X & X \\
Well 4 & X & X & X & X & X & X & X & X \\
\hline
\end{tabular}

$S P$ Spontaneous Potential log'; PHI Neutron Log; RHOB Density Log; $R$-MSFL, $R$ - LLS, $R$-LLD Resistivity $\operatorname{logs}$ 
Fig. 3 Map of the locations of wells drilled in the study area

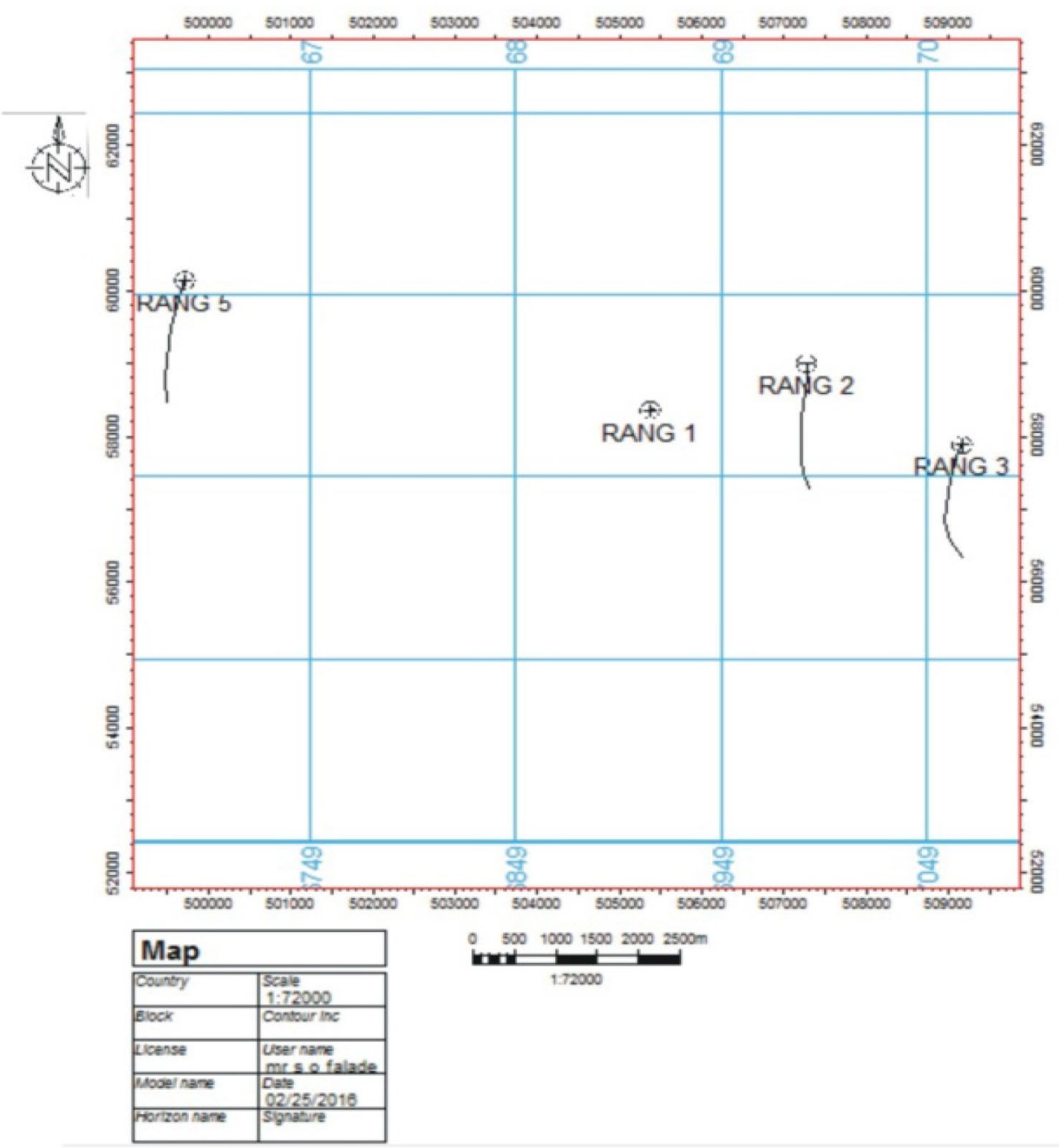

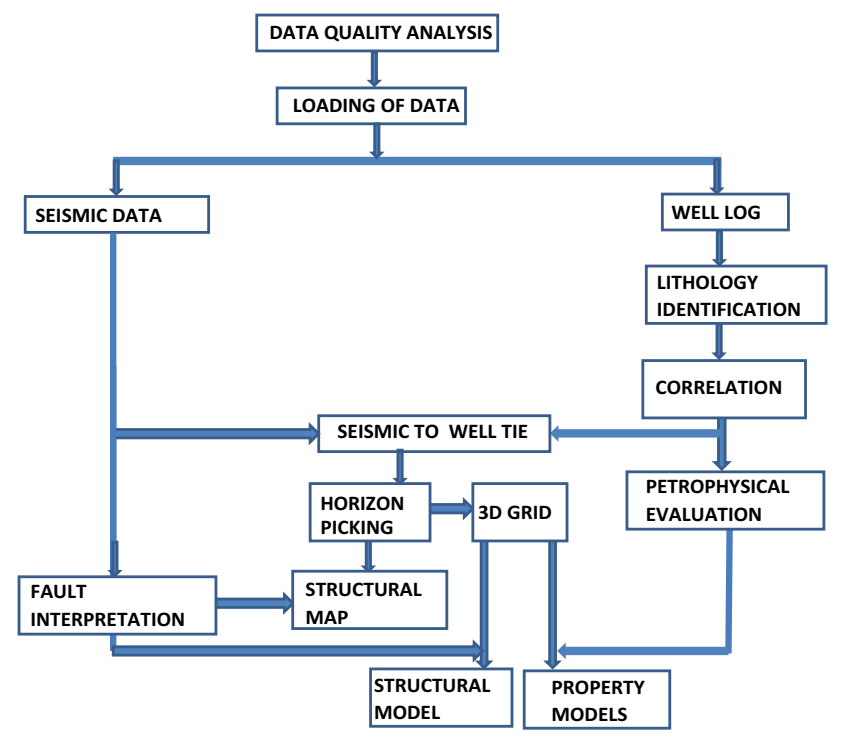

Fig. 4 Methodology workflow of the research work
Table 2 Matrix values for common types of rocks and fluids (Asquit and Krygowski, 2004)

\begin{tabular}{llll}
\hline Rock type & $\rho_{\mathrm{ma}}(\mathrm{g} / \mathrm{cc})$ & Fluid type & $\rho_{\mathrm{ma}}(\mathrm{g} / \mathrm{cc})$ \\
\hline Sandstone & 2.65 & Oil & 0.9 \\
Limestone & 2.71 & Fresh Water & 1.0 \\
Dolomite & 2.87 & Brine & 1.1 \\
Anhydrite & 2.98 & Rock type & $\rho_{\mathrm{ma}}(\mathrm{g} / \mathrm{cc})$ \\
\hline
\end{tabular}

$S_{w}=\sqrt{\frac{\mathrm{FR}_{w}}{R_{t}}}$

where $S_{w}=$ Water saturation, $R_{w}=$ Resistivity of water, $R_{t}=$ Resistivity of true formation.

The relationship between water saturation and hydrocarbon saturation is

$S_{w}+S_{\mathrm{hc}}=1$

where $S_{\mathrm{hc}}=$ Hydrocarbon (oil or gas) saturation. 

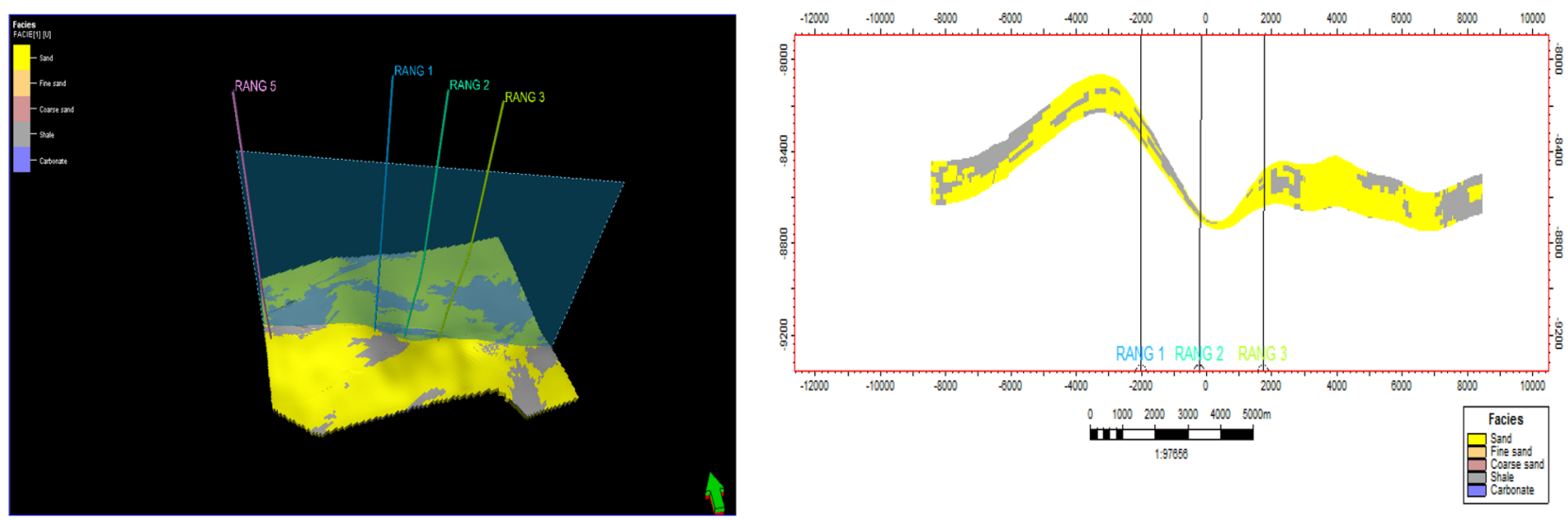

(a)

(b)

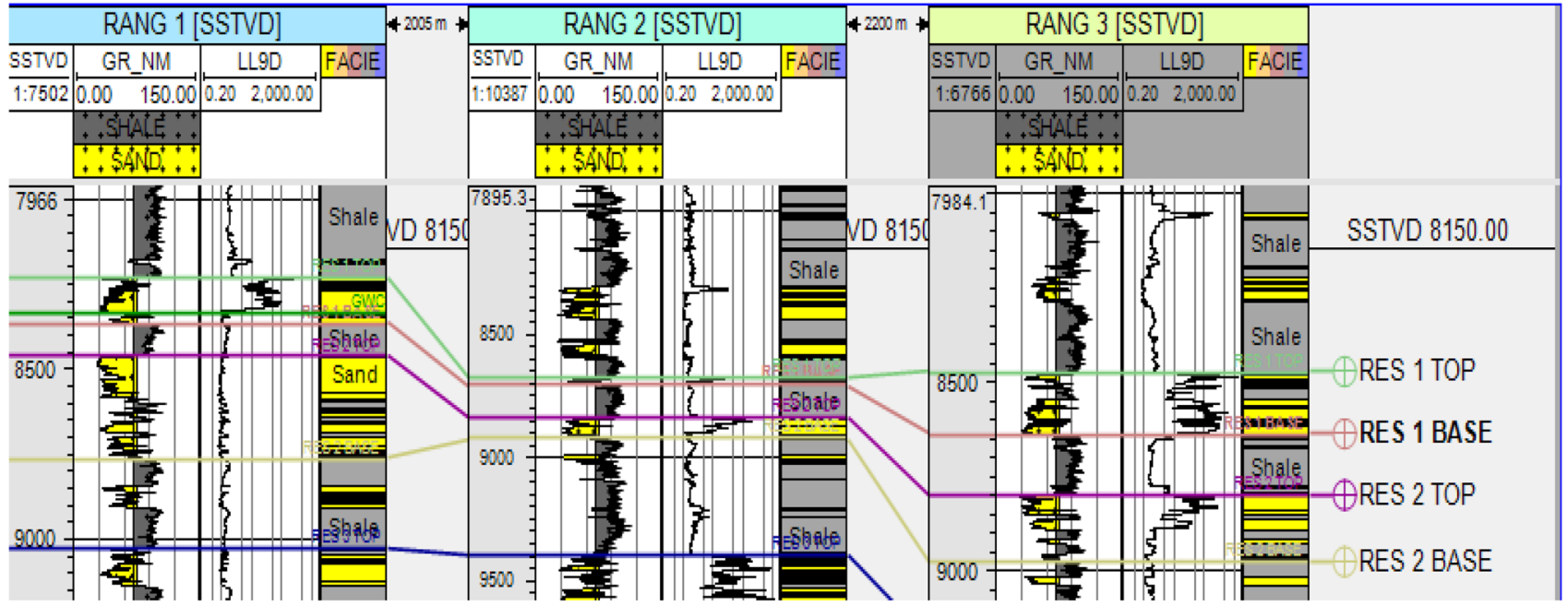

(c)

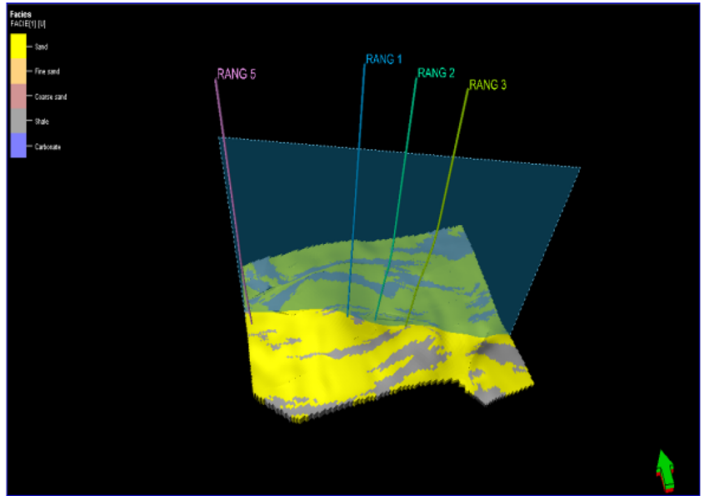

(d)

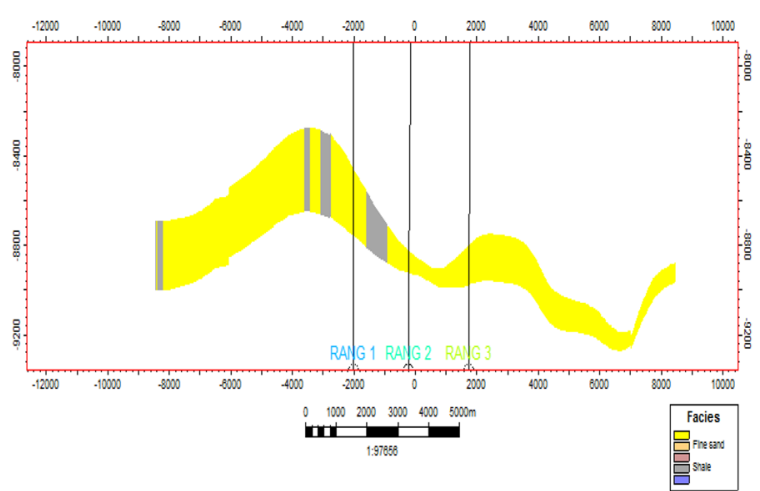

(e)

Fig. 5 a Direction of cross section of RES 1, b cross section of RES 1, $\mathbf{c}$ well correlation showing lithology variations in RES 1 and 2, d direction of cross section of RES 2, e cross section of RES 2 
NW

SE

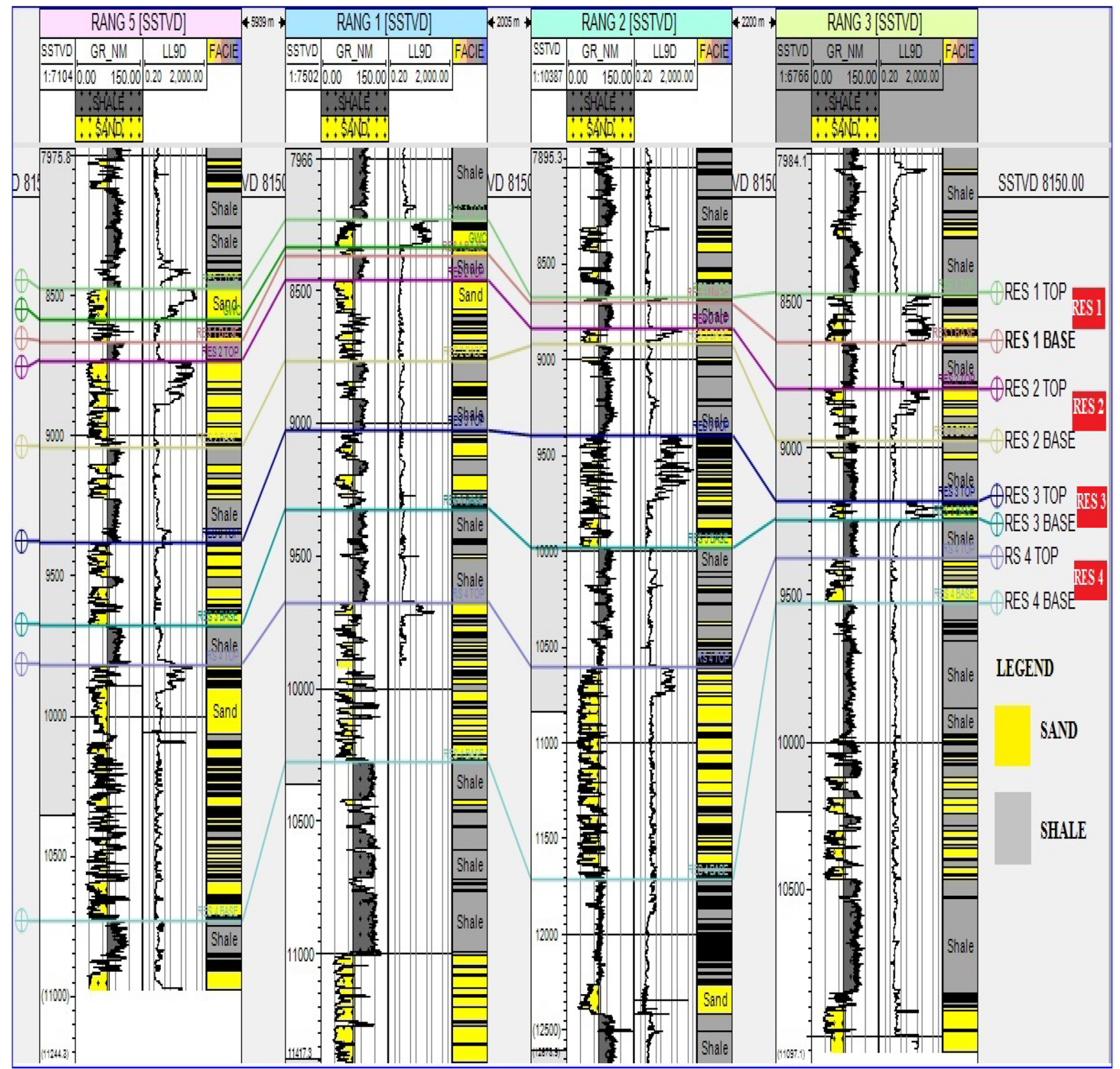

Fig. 6 Lithostratigraphic correlation of RANG 5, 1, 2 and 3 along NW-SE direction

\section{Seismic interpretation}

Seismic data were interpreted using some other valid information from well log data since well log data are point data with excellent resolution compared to seismic data which has a more lateral resolution but less vertical resolution. Some of the interpretations carried out on seismic data includes fault mapping by identifying the large-scale features, then successively mapping minor details. Establishing the relationship between seismic reflections and well logs was carried out through well to seismic tie. The check shot data were used to tie the synthetic seismogram obtained from the integration of sonic and density logs to the corresponding horizons on seismic data. Horizons that coincide with the top and base of 
the delineated reservoirs were picked to create surfaces used in 3D gridding. The basis of structural model employed was the depth converted seismic 3D interpretation. The imputed data for generation of the model include generated bounding reservoir surfaces, fault surface picked on seismic and their respective fault polygons.

\section{Reservoir modeling}

3D reservoir models were built using Petrel workflow tools. Gridding and layering were carried out. The reservoir properties derived from the petrophysical well logs were upscaled into the 3D grid in petrel after which data analysis (variogram analysis) was carried out. The geostatistical method used in combination with a simple krigging method in distributing the properties into the 3D geocellular models of the reservoir to produce the petrophysical models includes:

(I) Stochastic indicator simulation (SIS) for facies model;

(II) Stochastic Gaussian simulation (SGS) for NTG, water saturation and permeability models; and

(III) Gaussian random function simulation (GRFS) for porosity model

Several realizations of the models were generated for each property. Multiple realizations were run on the different reservoir properties, and a vertical slice for all of them was done and compared with the logs which show their vertical variation and the most realistic model for each of the properties were picked (Fig. 5).

\section{Results and discussion}

\section{Petrophysical analysis}

Figure 6 shows the correlation of the four wells with four reservoirs (RES 1-4) delineated in a NW-SE direction using the gamma ray log for lithological discrimination and the resistivity log to know the presence of hydrocarbon. The summary of the formation evaluation for all the reservoirs delineated from the four wells is shown in Table 3.

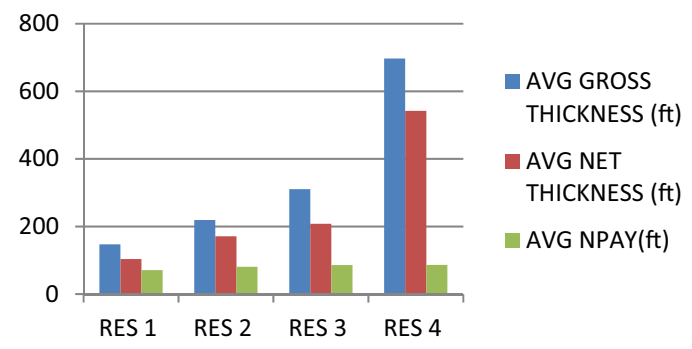

(a)

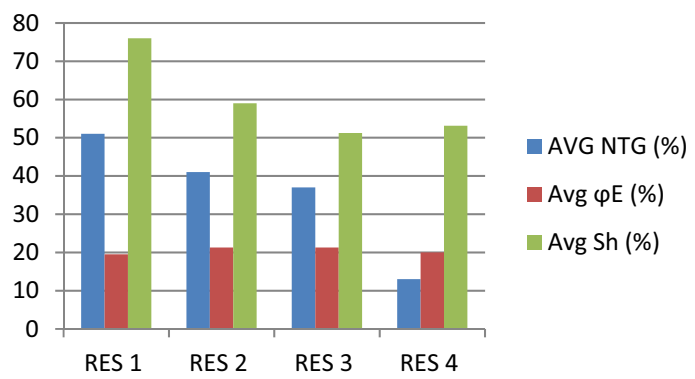

(b)

Fig. 7 a Variation in linear reservoir attributes, b variation in nonlinear reservoir attributes

Reservoir quality assessment was carried out from the formation evaluation, and the reservoirs were ranked according to their quality to know the ones to model. Firstly, using their linear physical attributes in terms of the properties that deals with thickness variation (gross thickness, net pay and net sand). RES 1 and 2 shows a moderate distribution of the gross thickness and net sand when compared with their respective net pay as they complement each other. The linear physical properties of Reservoirs 3 and 4 did not complement each other, i.e., high gross thickness and net sand but a low corresponding net pay value which shows the quality of the reservoir as shown in Fig. 7a. The ranking carried out based on the nonlinear physical attributes (hydrocarbon saturation, porosity, NTG) also shows that RES 1 and 2 is relative of higher quality than that of RES 3 and 4 as shown in Fig. 7b. Hence, Reservoirs 1 and 2 were picked for modeling.

Table 3 Summary of the reservoirs properties in 'Falad' field

\begin{tabular}{llllllllll}
\hline Reservoirs & $\begin{array}{l}\text { Avg Gross } \\
\text { Thickness } \\
(\mathrm{ft})\end{array}$ & $\begin{array}{l}\text { Avg Net Sand } \\
\text { Thickness (ft) }\end{array}$ & Avg NPay (ft) & Avg NTG (\%) & Avg $\varphi_{\mathrm{E}}(\%)$ & Avg $\varphi_{\mathrm{T}}(\%)$ & Avg K (md) & Avg S $(\%)$ & Avg $\mathrm{S}_{\mathrm{h}}(\%)$ \\
\hline RES 1 & 147.11 & 103.55 & 70.75 & 51 & 29.0 & 19.5 & 461.75 & 24.0 \\
RES 2 & 218.9 & 170.86 & 80.57 & 41 & 27.5 & 21.3 & 814.5 & 41.0 & 76.0 \\
RES 3 & 310.26 & 207.86 & 85.63 & 37 & 26.5 & 21.3 & 585.75 & 48.8 & 51.2 \\
RES 4 & 696.62 & 541.68 & 86.37 & 13 & 21.3 & 20.0 & 570 & 46.9 & 53.1 \\
\hline
\end{tabular}




\section{Seismic analysis}

Figure 8 shows some of the mapped faults (F1-F7) on inline 7220 in the seismic section. There are three major faults (F1, F3 and F4) which tend to occur almost across the seismic section. Two of these major faults observed (F1 and F3) were oriented in the SW-NE direction while the other one is F4 which is oriented in the NW-SE direction. Most of the faults in the area were oriented in the SW-NE direction.

From the synthetic seismogram generated, the events which correspond to the well tops to be used for mapping of the horizons to make their corresponding time and depth structure map as shown in Figs. 9 and 10 are listed, and they include:

RES 1 top horizon: Peak.
RES 1 base horizon: Zero crossover.

RES 2 top horizon: Trough in between peaks.

RES 2 base horizon: Trough (-ve peak).

Figures $11 \mathrm{a}, \mathrm{b}$ and $12 \mathrm{a}, \mathrm{b}$ show the structure time and depth maps of RES 1 and 2 tops, respectively. The contour values ranges with a contour interval of $15 \mathrm{~ms}$.

\section{Static modeling}

\section{Structural model of res 1 and 2}

Figure 13 shows the structural model generated which indicates the different orientation of the mapped fault $\mathrm{F} 1$ to F9. There are three major faults which tend to occur almost across the seismic section. Majority of the faults

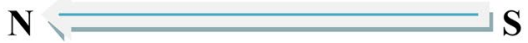

Fig. 8 A Seismic section showing faults (F1-F7) on Inline 7220

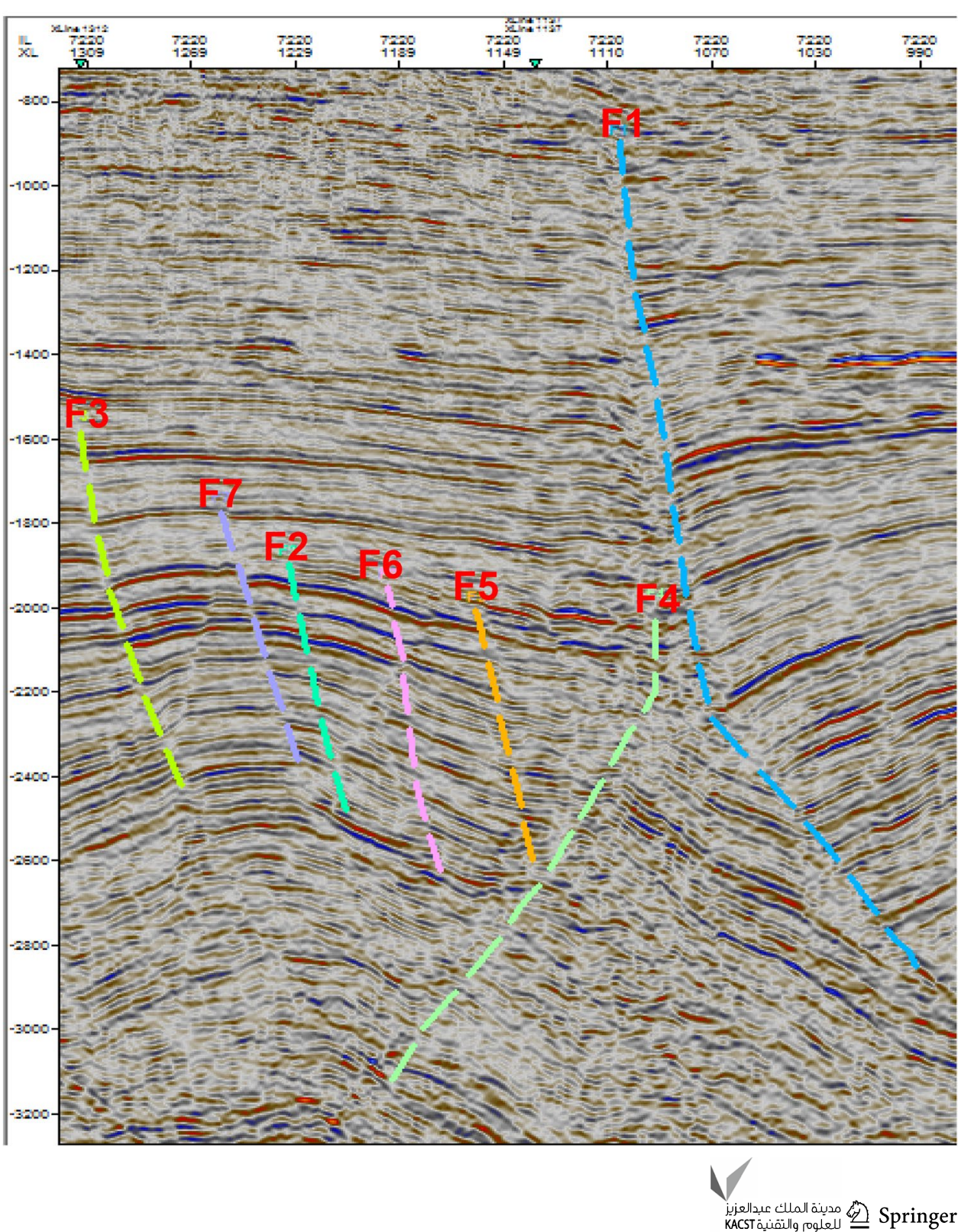


were oriented in the SW-NE direction while only fault F4 is oriented in the NW-SE direction. Most of the faults in the area were oriented in the SW-NE direction.

\section{Facies model of res 1 and 2}

Figure 14 shows the facies models in 3D. The facies is only subdivided into the reservoir-sand (yellow color) and non-reservoir-shale (gray color). It was observed that the sand body was distributed moderately in the entire field.

\section{Net To gross model of res 1 and 2}

Net to gross models generated are shown in Fig. 15 which reveals an excellent net to gross across the entire field which is indicative of moderate to good net to gross which ranges between 0.77 and 0.95 . This property has its distribution to be similar to facies across the whole field when the two models were compared.

\section{Porosity model of res 1 and 2}

Figure 16 reveals the porosity models in 3D showing the status of good porosity distribution (20-37\%) in the entire field. This result indicates that the pore spaces in these reservoir sands have adequate space to accommodate fluids.

\section{Water saturation model of res 1 and 2}

3D model for the water saturation is shown in Fig. 17 which reveals that the water saturation distribution in the study area varies from 0.3 to 0.4 . This result suggests that the study area is a region of more hydrocarbon zone. It was also observed that the new prospect areas could be in the central and some parts of the southwestern and northeastern parts of the field which shows an average water saturation of 0.25 corresponding to high hydrocarbon saturation.

\section{Permeability model of res 1 and 2}

The 3D view of the permeability models is shown in Fig. 18 ranging from 87 to $837 \mathrm{md}$. The models show a reflection of good connection of the pore spaces and their ability to

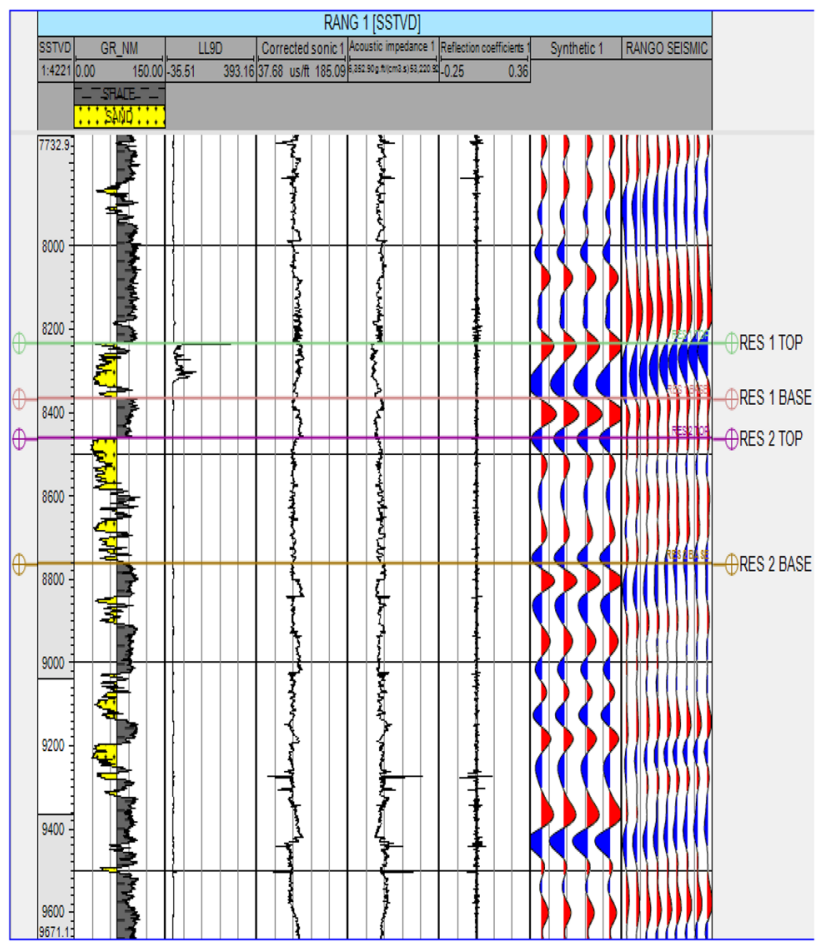

Fig. 9 Synthetic seismogram

transmit fluids in the reservoir sands within the well areas. In contrary, some parts in the north and southwest that is far away from the well areas are indicative of poor to fair permeability.

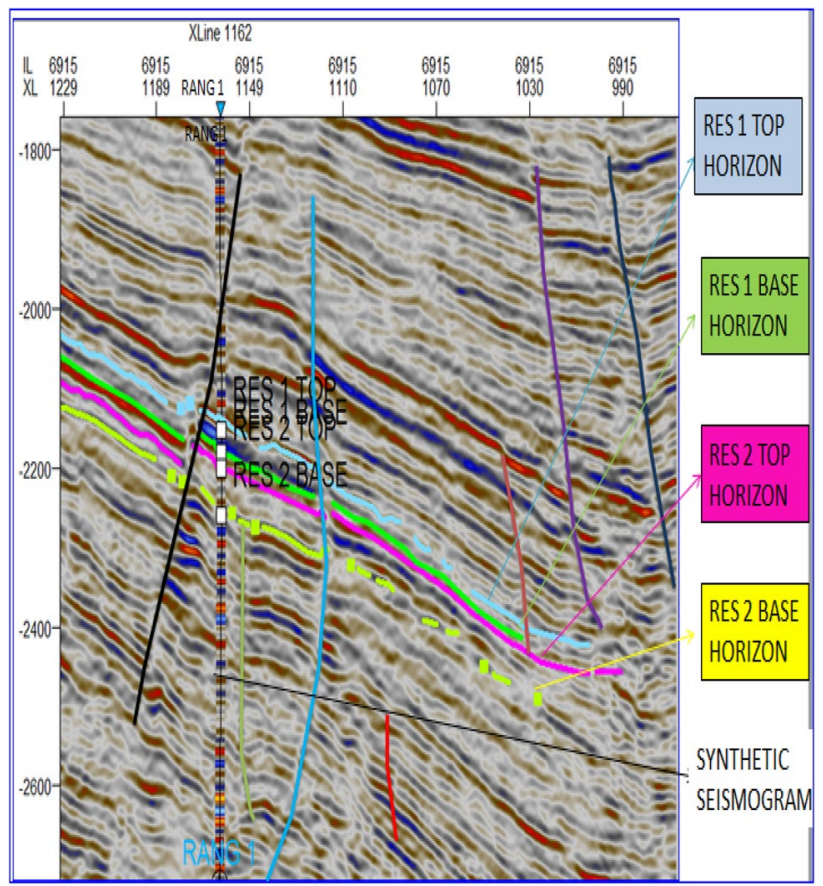

Fig. 10 Well to seismic tie and picked horizons 


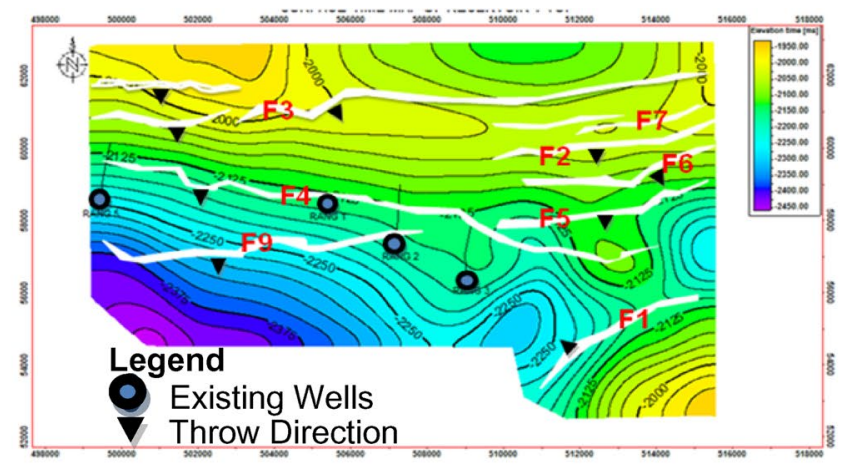

(a)

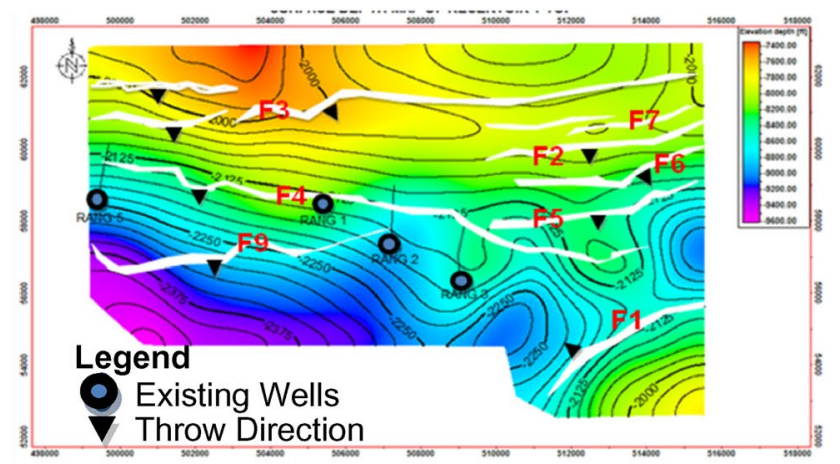

(b)

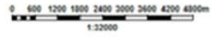

Fig. 11 a Time structural map of RES 1 top horizon, $\mathbf{b}$ depth structural map of RES 1 top horizon

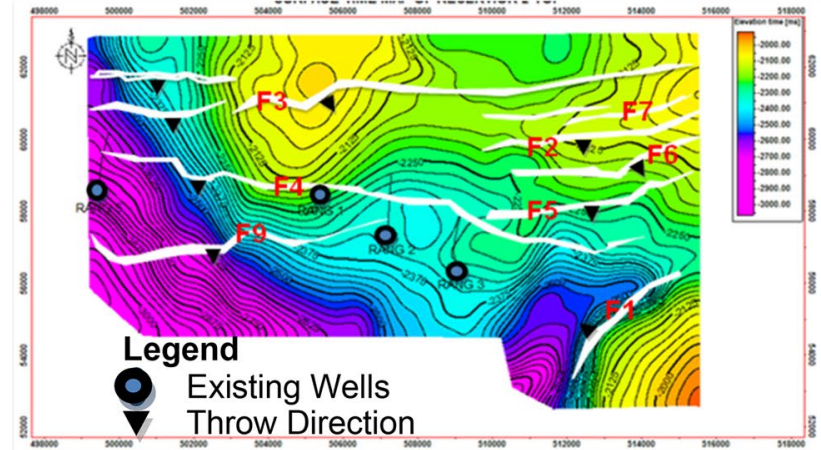

(a)

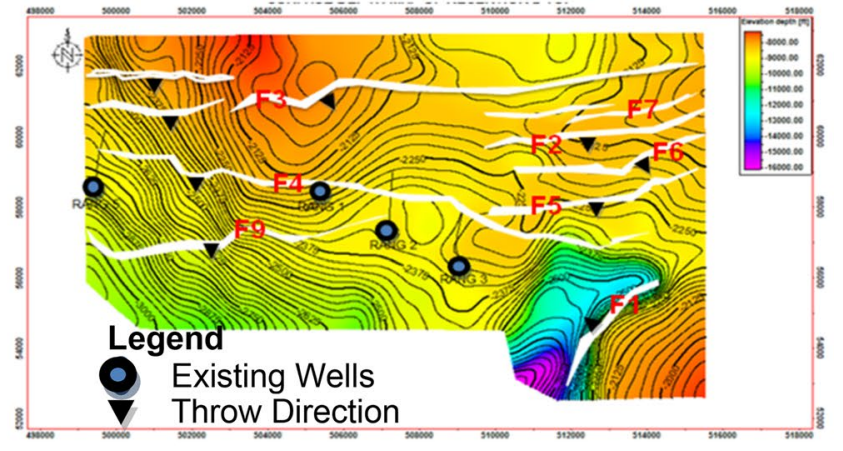

(b)

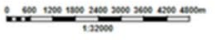

Fig. 12 a Time structural map of RES 2 top horizon, b depth structural map of RES 2 top horizon

\section{Prospect mapping}

Prospective zones were mapped out from models by comparing the probabilistic behavior of the reservoir properties in the area as shown through the property models (Fig. 19). Those portions with relatively high quality of the property displayed were mapped out as shown in Fig. 19. These models aided in determining the distribution and quality of the reservoir, thereby getting more prospects. The structural closures labeled as A and B in Fig. 20 were also mapped out as prospects. Two new prospective areas were mapped from the property models. Prospect 'A' shown in Fig. 21 is similar to the Prospect ' $\mathrm{A}$ ' identified on the structural maps which serve as a form of affirmation. The distribution and quality of the reservoir gave us a good knowledge of some potential points in the field.

\section{Conclusions}

In conclusion, the application of geostatistics has given us insight into the distribution of the petrophysical properties in the study area. Geostatistics has proved to be reliable considering the geology of the area and the sparsity of the available well data. Geostatistics have helped in populating petrophysical properties into a 3D model, revealing that all petrophysical parameters can be modeled for better understanding of any field. The heterogeneity of data is significantly reduced through geostatistics, thereby making decision to be more accurate and easier. Since well logs are point data, showing the cross section of the derived models and comparing the realizations with well logs aided the decision of selecting the most realistic realization out of the multiple realizations produced. This has created a way of comparing well logs with geostatistical models even though proximity of the local areas to well will tend to have effect on the results from geostatistical model. The results also confirm that applying simple krigging method 
Fig. 13 3D Structural model of reservoirs 1 and 2 in 'Falad' Field
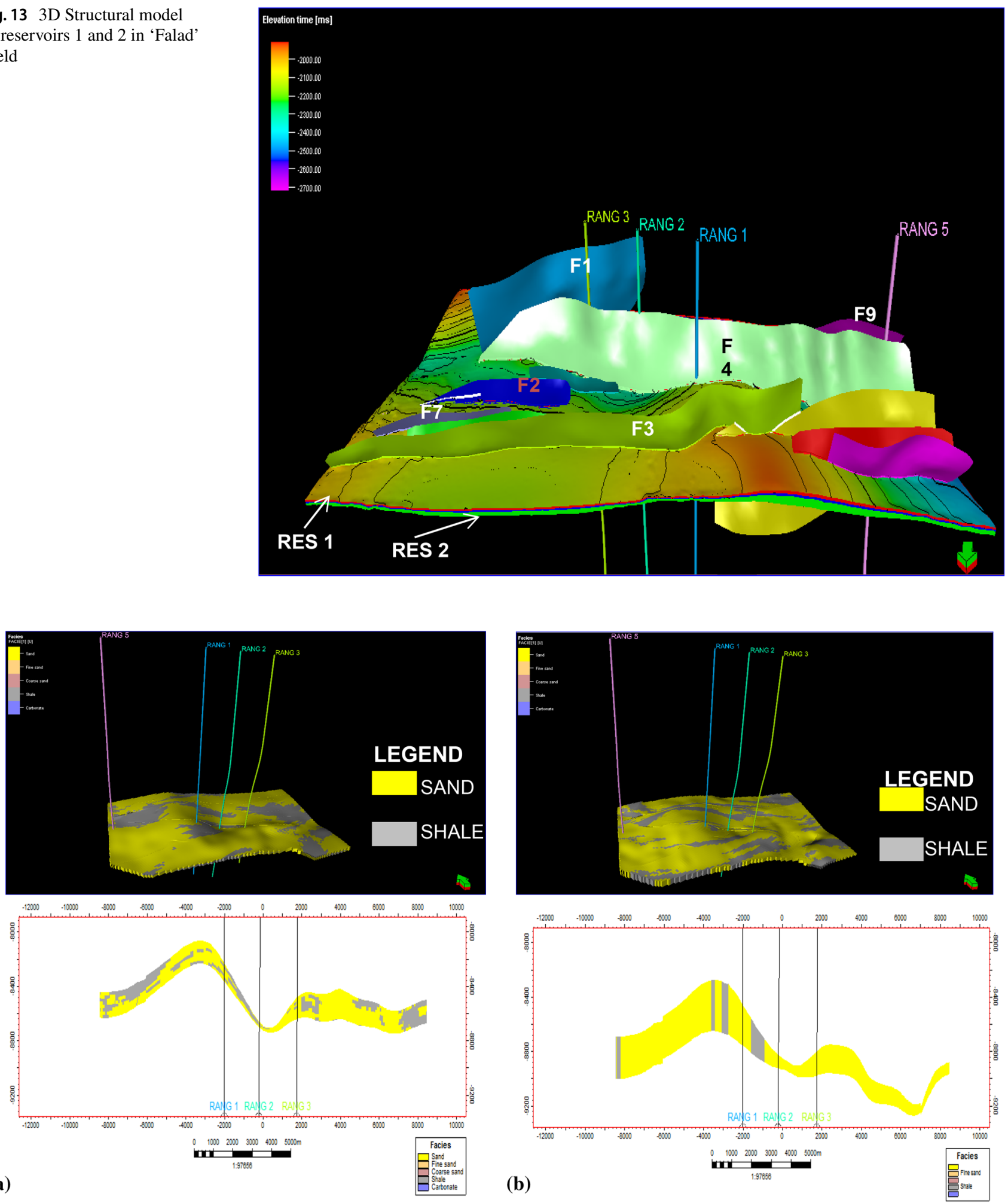

(b)

being modeled produces the best possible subsurface representation of the local areas deficient of well log data. The results of this study have also been able to identify a indicator simulation (SIS) and Gaussian random function simulation (GRFS) algorithms, depending on the property 

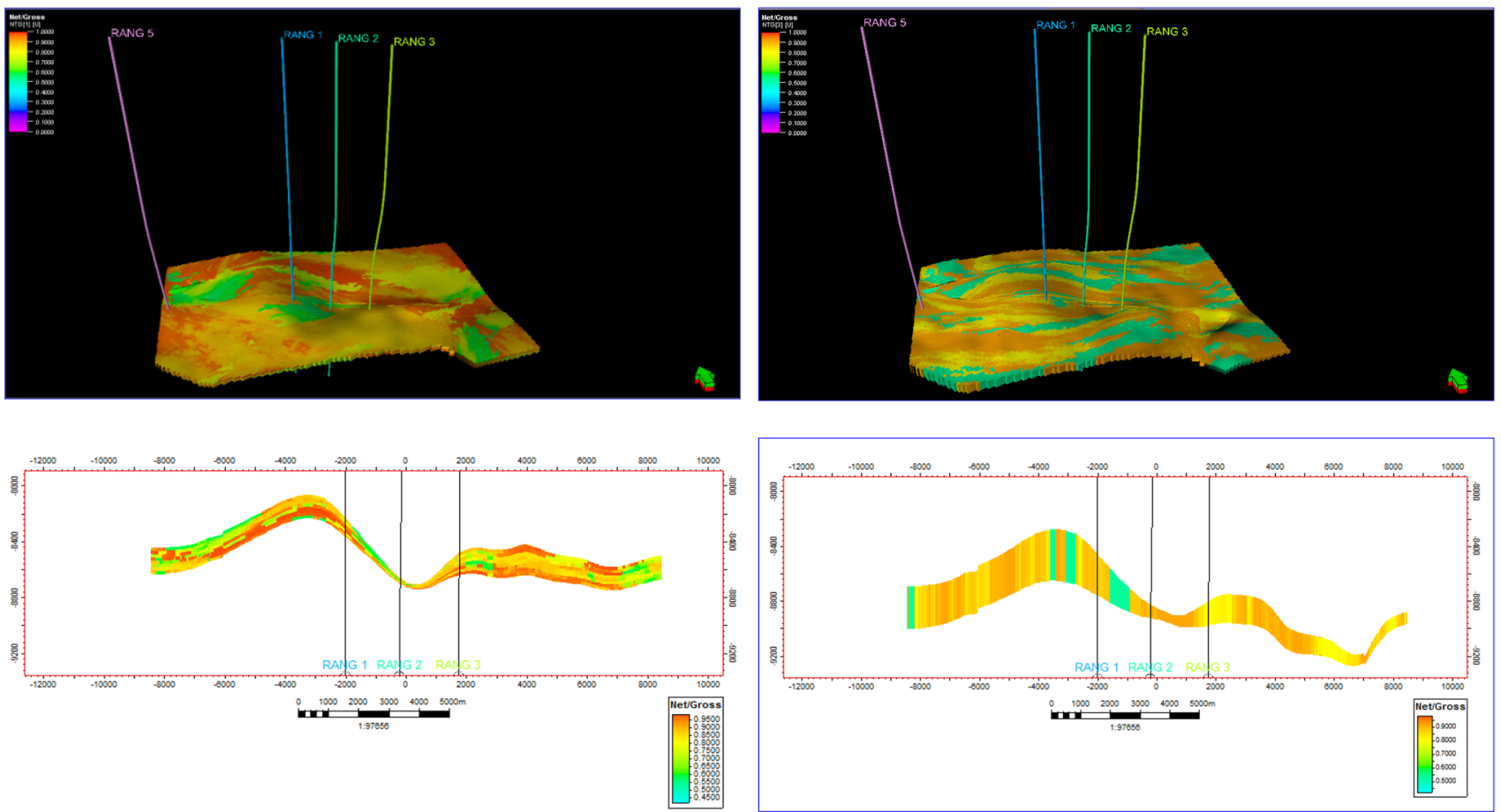

(a)

(b)

Fig. 15 Net to gross model for: a RES 1, b RES 2
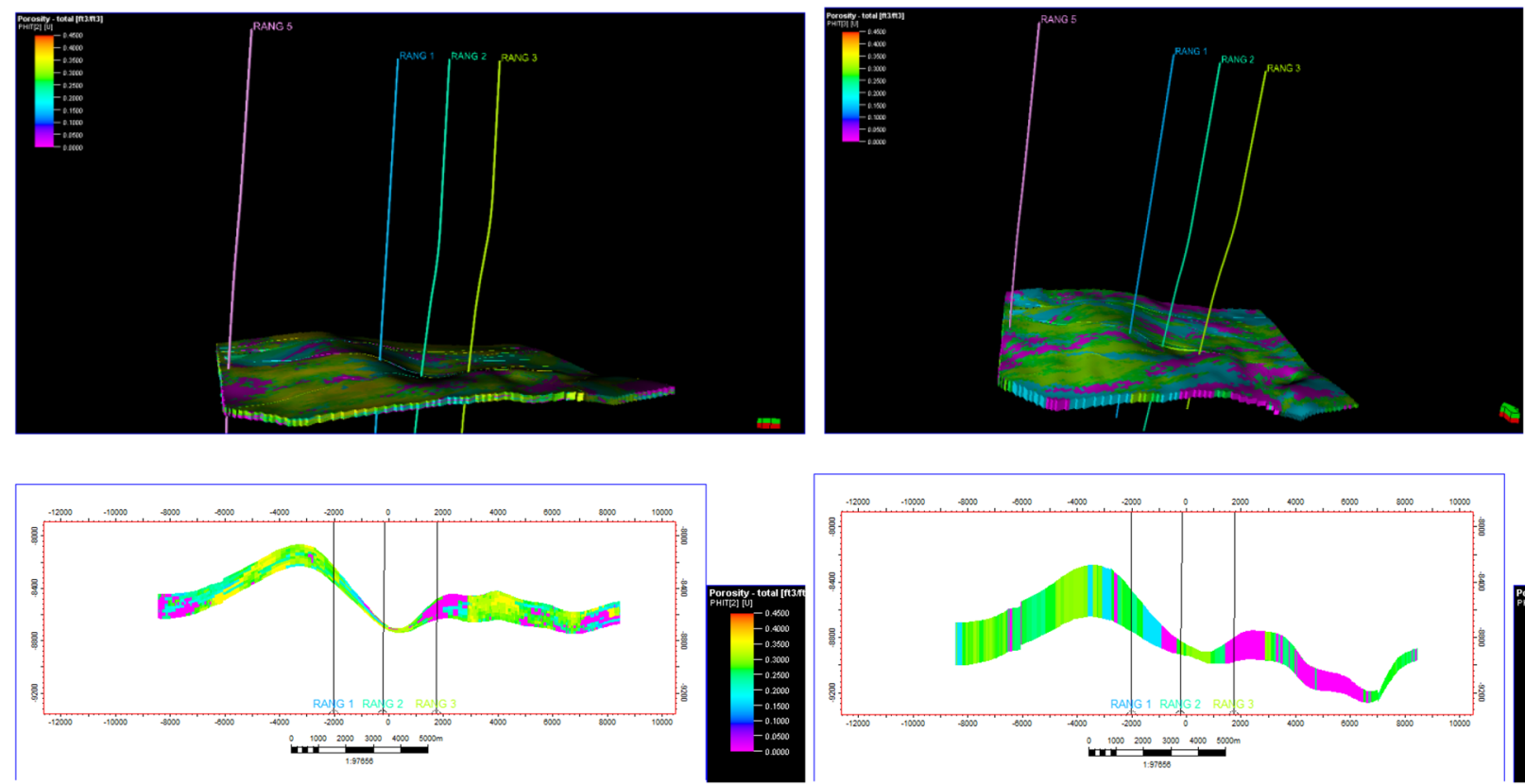

(a)

(b)

Fig. 16 Porosity model for: a RES 1, b RES 2

new possible position with good reservoir qualities using modeling. As this study validates the use of geostatistical modeling, it is recommended that more well data be used for further studies and petrophysical parameters be accurately estimated when carrying out geostatistical modeling to avoid inputting wrong information into the $3 \mathrm{D}$ grid. 

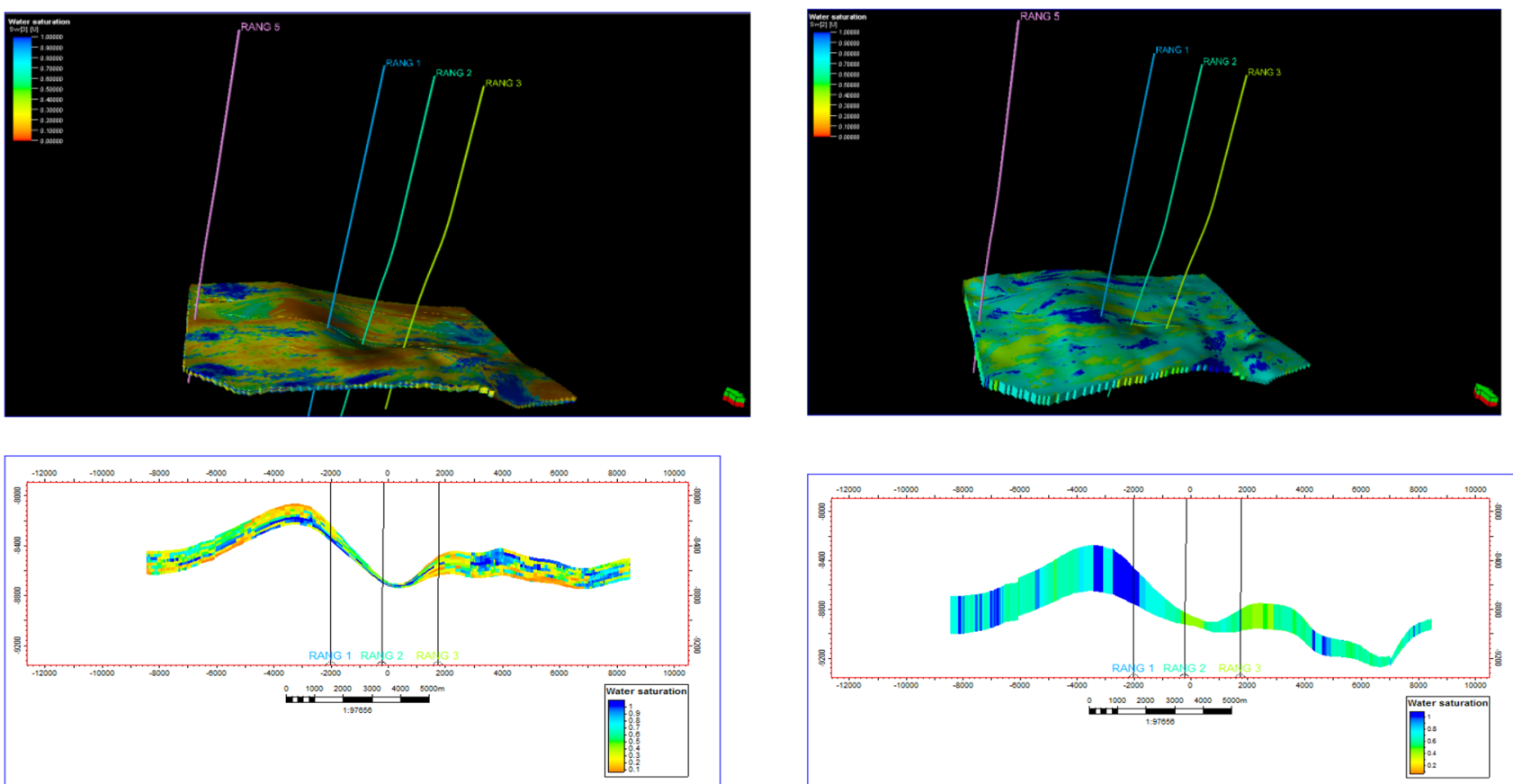

(a)

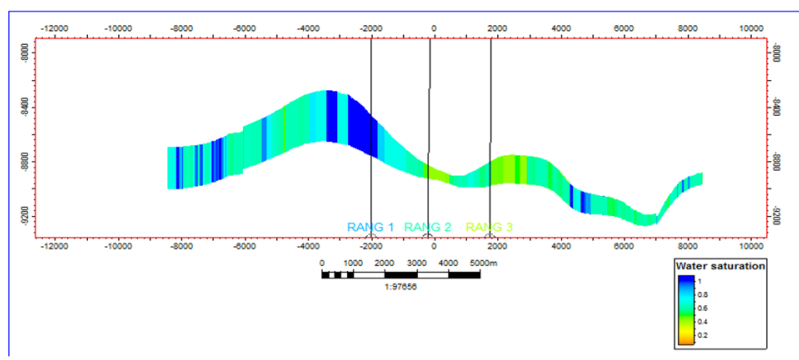

(b)

Fig. 17 Water saturation model for: a RES 1, b RES 2
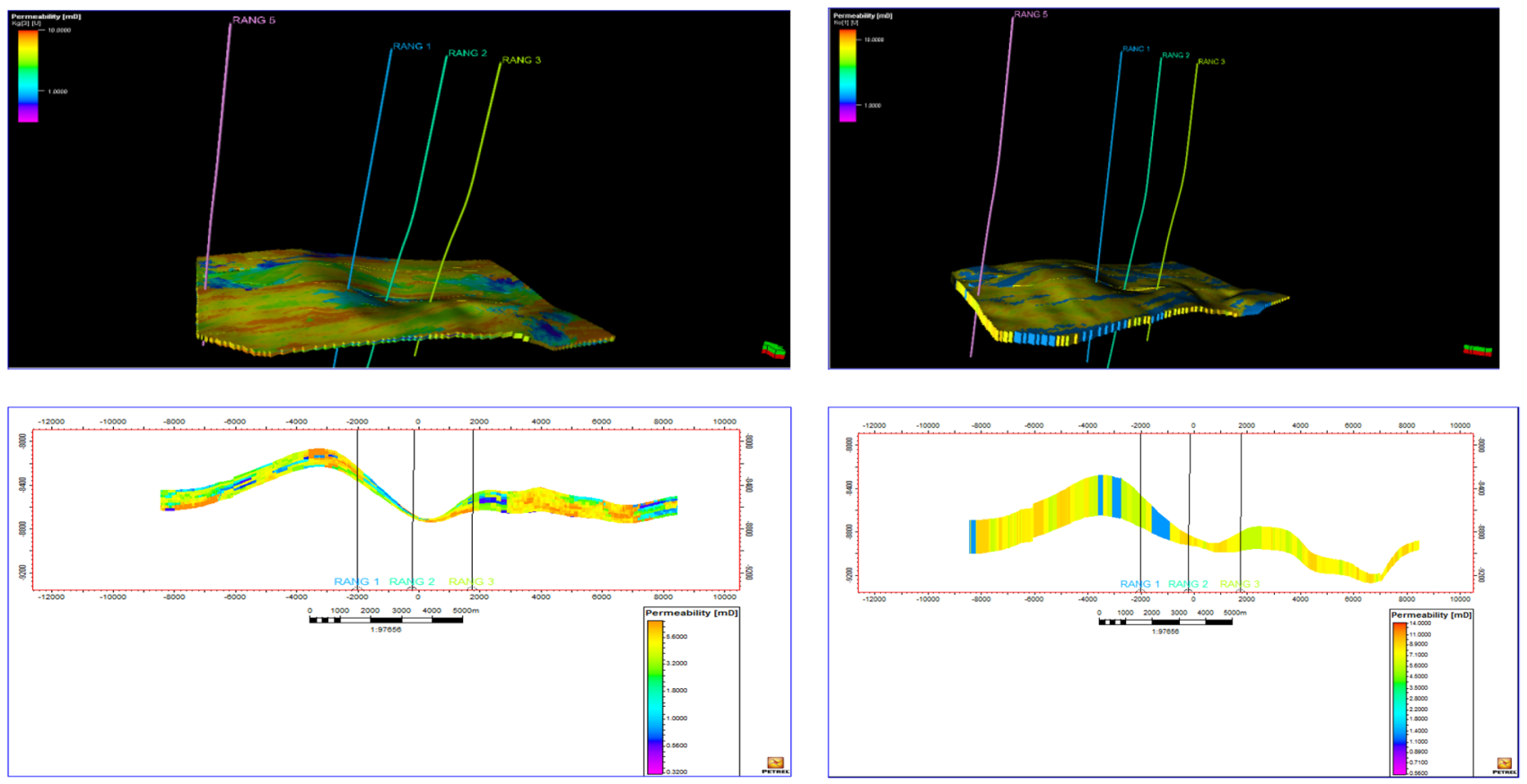

(a)

(b)

Fig. 18 a Permeability model of RES 1, b permeability model of RES 2 


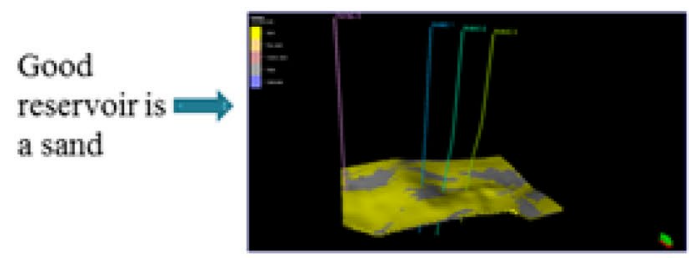

LITHOLOGY
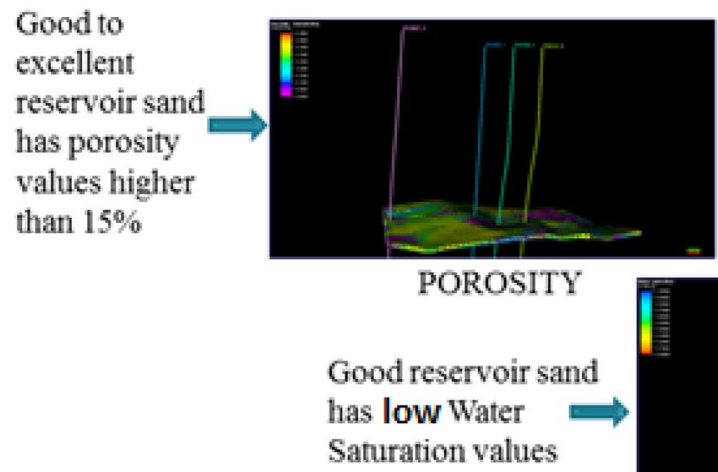

(a)

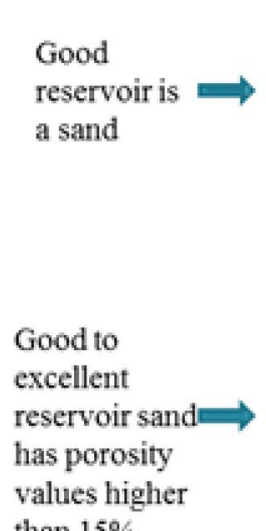

than $15 \%$

(b) Saturation values
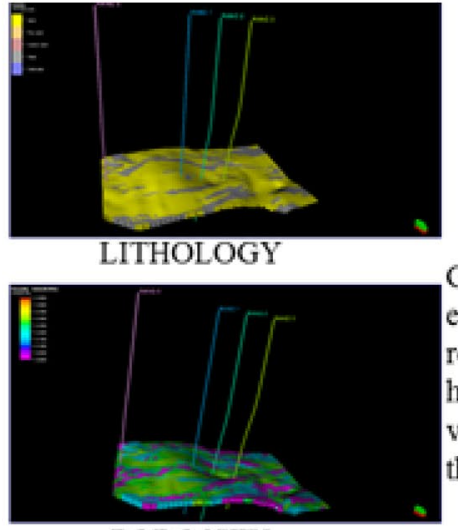

POROSITY

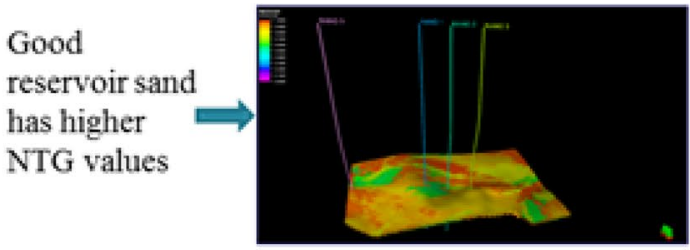

NET TOGROSS

Good to excellent reservoir sand has permeability values higher than 50md

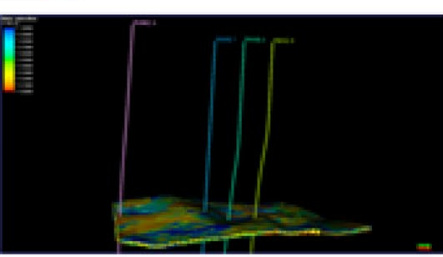

WATER SATURATION

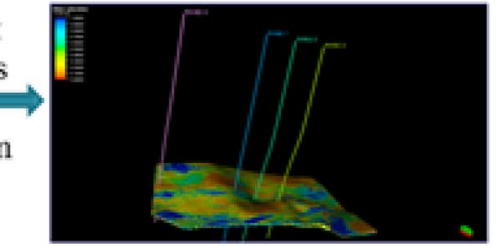

PERMEABILITY
Good reservoir sand has $\Rightarrow$ higher NTG values

\section{Good to} excellent reservoir sand $\Longrightarrow$ has permeability values higher than $50 \mathrm{md}$

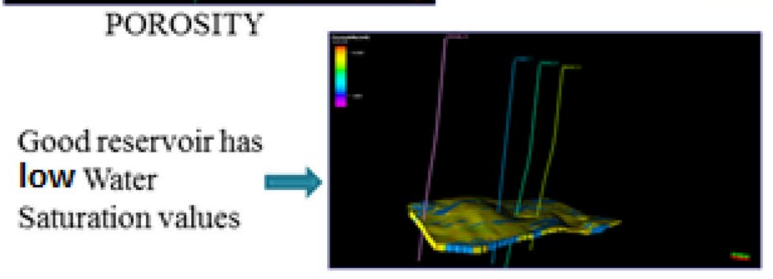

WATER SATURATION

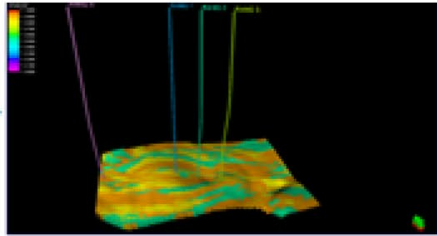

NET TOGROSS

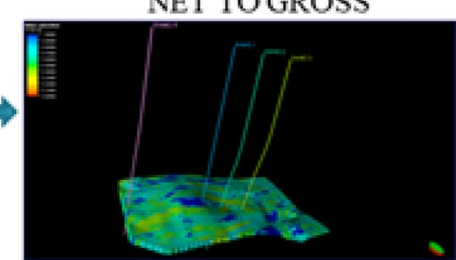

PERMEABILITY

Fig. 19 a Reservoir 1 quality distribution assessment comparison and mapping of areas with good reservoir properties, b Reservoir 2 quality distribution assessment comparison and mapping of areas with good reservoir properties 


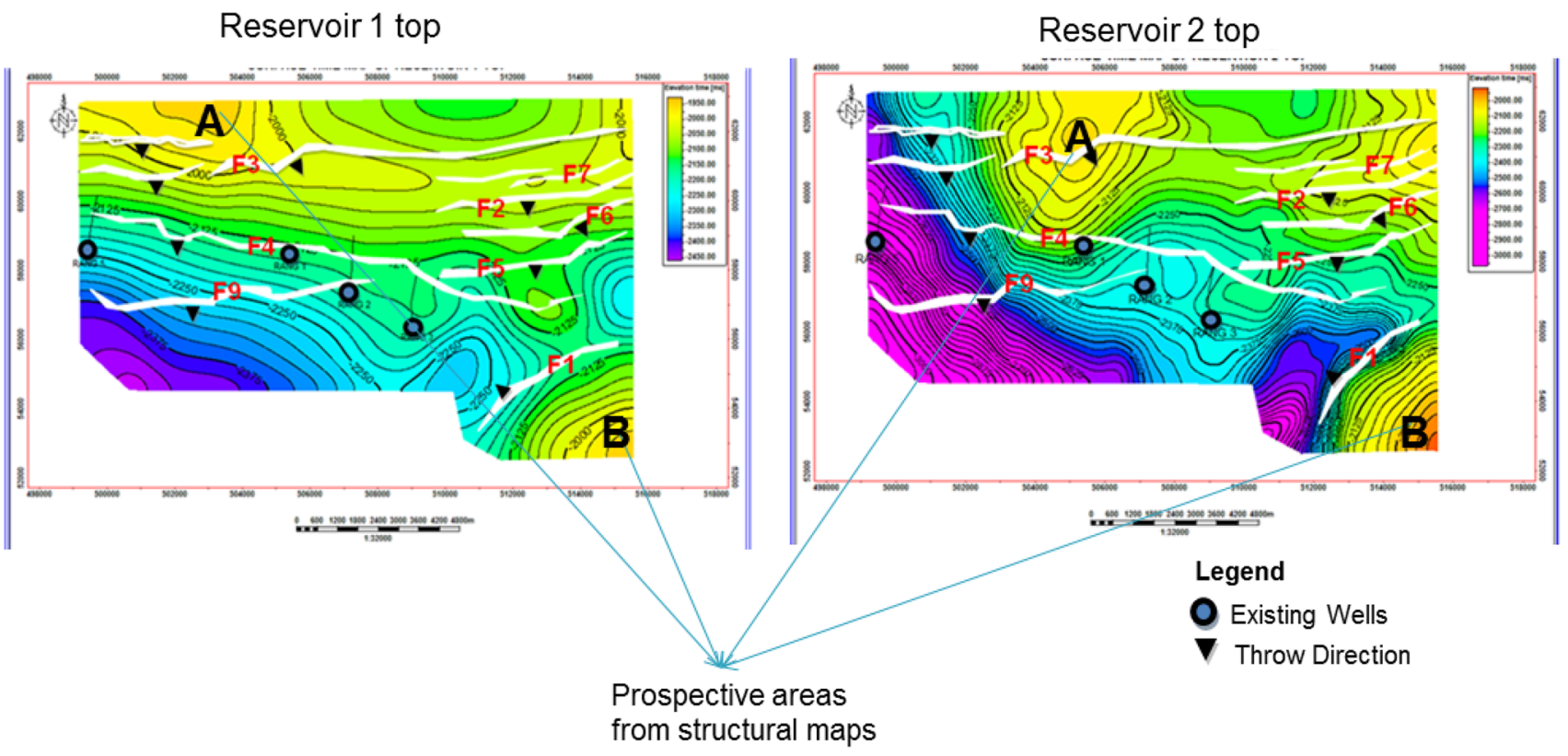

Fig. 20 Prospect map from structural map

Fig. 21 Prospect map from models

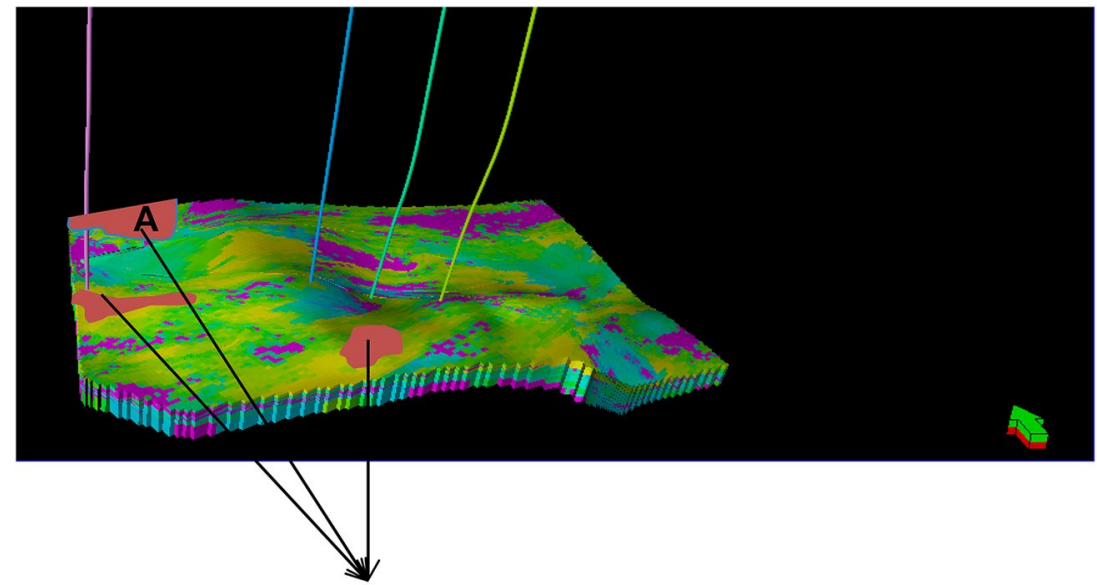

Prospective areas from property models

Acknowledgements We appreciate the Nigerian Petroleum Development Company, NPDC, for giving us the data with which made this research to be possible.

\section{Funding None.}

\section{Declarations}

Conflict of interest The authors declared that they have no conflict of interest.

Open Access This article is licensed under a Creative Commons Attribution 4.0 International License, which permits use, sharing, adaptation, distribution and reproduction in any medium or format, as long as you give appropriate credit to the original author(s) and the source, provide a link to the Creative Commons licence, and indicate if changes were made. The images or other third party material in this article are included in the article's Creative Commons licence, unless indicated otherwise in a credit line to the material. If material is not included in the article's Creative Commons licence and your intended use is not permitted by statutory regulation or exceeds the permitted use, you will need to obtain permission directly from the copyright holder. To view a copy of this licence, visit http://creativecommons.org/licenses/by/4.0/.

\section{References}

Aigbedion I, Aigbedion H (2011) Hydrocarbon volumetric analysis using seismic and borehole data over Umoru field, Niger DeltaNigeria. Int J Geosci. https://doi.org/10.4236/ijg.2011.22019 
Al-Baldawi BA (2014) Petrophysical evaluation study of Khasib Formation in amara oil field, South Eastern Iraq. Arab J Geosci. https://doi.org/10.1007/s12517-014-1371-5

Asquith G, Krygowski D (2004) Basic Well Log Analysis. AAPG Methods in Exploration Series, No. 16, 2004

Akpoyovbike Abogo Avbovbo (2). (1978) "Tertiary Lithostratigraphy of Niger Delta: GEOLOGIC NOTES", AAPG Bulletin

Azeez O (1976) The stratigraphy, sedimentation and structure of the Niger Delta. In: Kogbe CA (ed) Geology of Nigeria. Elizabethan Pub. Co, Lagos, pp 259-271

Azuka A (2009) "Uncertainty Evaluation in Field Development and Export Planning", Proceedings of EUROPEC/EAGE Conference and Exhibition EURO, 06/2009

BP (2014). Statistical review of world energy. www.bp.com/statistica lreview

Chambers RL, Yarus JM (2010) "Practical geostatistics"—An armchair overview for petroleum reservoir engineers, SPE 103357. J Petrol Technol 2006:78-86

Chapin M, Swinburn P, van der Weiden R, Skaloud D, Adesanya S, Stevens D, Varley C, Wilkie J, Brentjens E, Blaauw M (2002) Integrated seismic and subsurface characterization of Bonga Field, offshore Nigeria. Lead Edge 21:1125-1131

Chopra S, Marfurt K (2007) Seismic attributes for prospect identification and reservoir characterization: Geophysical Development Series No. 11, SEG, 123-151

Contreras A, Torres-Verdin C, Chesters W, Kvien K, Globe M (2005) Joint stochastic inversion of petrophysical logs and 3D prestack seismic data to assess the spatial continuity of fluid units away from wells: application to a Gulf of Mexico deep water hydrocarbon reservoir: 46th Annual Logging Symposium, SPWL

Corredor F, Shaw JH, Bilotti F (2005) Structural styles in the deepwater fold and thrusts belts of the Niger Delta. AAPG Bull $89: 753-780$

Doust H, Omatsola M (1990) Petroleum geology of the Niger delta Geological Society, London. Special Publ 50:365-365

Ebong ED, Akpan AE, Ekwok SE (2019) Stochastic modelling of spatial variability of petrophysical properties in parts of the Niger Delta Basin, southern Nigeria. J Petrol Explor Prod Technol 10:569-585

Edigbue P, Olowokere MT, Adetokunbo P, Jegede E (2015) Integration of sequence stratigraphy and geostatistics in 3-D reservoir modeling: a case study of Otumara field, onshore Niger Delta. Arab J Geosci 8(10):8615-8631

Liu E, Chapman M, Hudson JA, Tod SR, Maultzsch S, Li XY (2005) Quantitative determination of hydraulic properties of fractured rock using seismic techniques. Geol Soc London Special Publ 249(1):29-42

Evamy B, Haremboure J, Kamerling P, Knaap W, Molloy F, Rowlands P (1978) Hydrocarbon habitat of Tertiary Niger delta. AAPG Bull 62:1-39

Fournier A (1995) Wavelet representation of lower-atmospheric long nonlinear wave dynamics, governed by the
Benjamin-Davis-Ono-Burgers equation SPIE's 1995 Symposium on OE/Aerospace Sensing and Dual Use Photonics, 672-681

Fowler, M. L., Young, M.A., Madden, M.P. and Cole, E.L. (1999). "The Role of Reservoir Characterization in the Reservoir Management Process". In: Schatzinger R, Jordan J (Eds) Reservoir Characterization - Recent Advances, AAPG Memoir 71, 3-18

Gadallah MR, Fisher R (2009) Exploration geophysics. Springer, BerlinHeidelberg, p 262

Hepler GF, Gaynor JM, Thornton M (1998) “The Importance of reservoir Characterization in the Belida Field development". Society of Petroleum Enginners, SPE 39718-MS

Ihunda Chigozi Eze, Adiela U. P and Ogbumgbada Igochi Fortune (2017). Paleoenvironmental Analysis Outcrop In Akpoha Afikpo Basin South Eastern, Nigeria. IJSIT, 2017, 6(2), 138-146

Li XY, Liu Y, Liu E, Shen F, Qi L, Shouli Q (2003) Fracture detection using land 3D Seismic data from the Yellow River Delta, China. Lead Edge 22:680-683. https://doi.org/10.1190/1.1599696

Mukerji J, Narayanan TK, Christian BT, Shi B, Yang ZY (2004) "Binding Characteristics of High-affinity dopamine D2/D3 receptor agonists, 11C-PPHT and 11C-ZYY-339 in rodents and imaging in non-human primate by PET. Synapse 2004(54):83-91

Kafisanwo OO, Falade AO, Bakare OV, Oresanya AA (2018) Reservoir characterization and prospect identification in Onka field, offshore, Niger Delta. Environ Earth Sci Res J 5(4):79-86. https:// doi.org/10.18280/eesrj.050401

Opara AI (2010) Prospectivity evaluation of "“Usso Field”, Onshore Niger Delta basin using 3-D seismic and Well log data. Petrol Coal 52(4):307-315

Short KC, Stauble A (1967) Outline geology of Niger Delta. Am Assoc Pet Geol 51:761-776

Swinburn P, van der Weiden R (2015) Bonga Field-An integrated approach to subsurface modeling in an uncertain world. 63rd Conference \& Exhibition, EAGE, Extended Abstracts, 1-5.Acts, $61-65$

Mukerji T (2001) "Statistical rock physics: Combining rock physics, information theory, and geostatistics to reduce uncertainty in seismic reservoir characterization", The Leading Edge, 03/2001

Davis TL (1999) "4-D, 3-C seismology and dynamic reservoir characterization-A geophysical renaissance", SEG Technical Program Expanded Abstracts

Weber KJ (1971) Sedimentological aspects of oil fields in the Niger Delta. Geol En Mijnbouw 50(1):559-576

Weber KJ, Daukoru E (1975) Petroleum geology of the Niger Delta. Proceedings of the 9th World petroleum congress held in Tokyo, Japan, May 11-16, 209-221

Zhao X, Qi K, Liu Li, Gong C, McCaffrey WD (2018) Development of Partially-avulsed submarine channel on the Niger Delta continental slope: architecture and controlling factors. Marine Petreol Geol 95(2018):30-49. https://doi.org/10.1016/j.marpetgeo.2018.04.015 